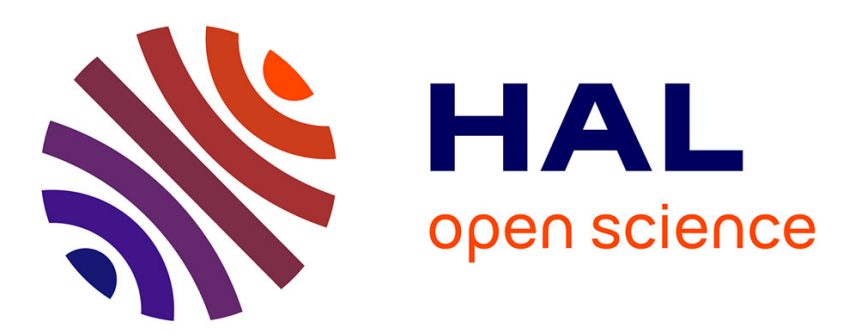

\title{
Highly valuable microalgae: biochemical and topological aspects
}

Olivier Pignolet, Sébastien Jubeau, Carlos Vaca-Garcia, Philippe Michaud

\section{To cite this version:}

Olivier Pignolet, Sébastien Jubeau, Carlos Vaca-Garcia, Philippe Michaud. Highly valuable microalgae: biochemical and topological aspects. Journal of Industrial Microbiology and Biotechnology, 2013, 40 (8), pp.781-796. 10.1007/s10295-013-1281-7 . hal-02067092

\section{HAL Id: hal-02067092 \\ https://hal.science/hal-02067092}

Submitted on 14 Mar 2019

HAL is a multi-disciplinary open access archive for the deposit and dissemination of scientific research documents, whether they are published or not. The documents may come from teaching and research institutions in France or abroad, or from public or private research centers.
L'archive ouverte pluridisciplinaire HAL, est destinée au dépôt et à la diffusion de documents scientifiques de niveau recherche, publiés ou non, émanant des établissements d'enseignement et de recherche français ou étrangers, des laboratoires publics ou privés. 


\section{Open Archive Toulouse Archive Ouverte (OATAO)}

OATAO is an open access repository that collects the work of Toulouse researchers and makes it freely available over the web where possible

This is an author's version published in: http://oatao.univ-toulouse.fr/23263

Official URL: https://doi.org/10.1007/s10295-013-1281-7

\section{To cite this version:}

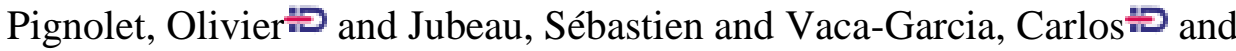
Michaud, Philippe Highly valuable microalgae: biochemical and topological aspects. (2013) Journal of Industrial Microbiology and Biotechnology, 40 (8). 781-796. ISSN 1367-5435

Any correspondence concerning this service should be sent to the repository administrator: tech-oatao@listes-diff.inp-toulouse.fr 


\title{
Highly valuable microalgae: biochemical and topological aspects
}

\author{
Olivier Pignolet • Sébastien Jubeau • \\ Carlos Vaca-Garcia • Philippe Michaud
}

\begin{abstract}
The past decade has seen a surge in the interest in microalgae culture for biodiesel production and other applications as renewable biofuels as an alternative to petroleum transport fuels. The development of new technologies for the culture of these photosynthetic microorganisms and improved knowledge of their biochemical composition has spurred innovation in the field of highvalue biomolecules. These developments are only economically viable if all the microalgae fractions are valorized in a biorefinery strategy. Achieving this objective requires an understanding of microalgae content and the cellular localization of the main biomolecular families in order to develop efficient harvest and sequential recovery technologies. This review summarizes the state of the art in microalgae compositions and topologies using some examples of the main industrially farmed microalgae.
\end{abstract}

Keywords Biorefinery $\cdot$ Cyanobacteria $\cdot$ Eukaryotic microalgae $\cdot$ Biofuel $\cdot$ Lipid $\cdot$ Polysaccharide $\cdot$ Pigment . Protein

O. Pignolet · C. Vaca-Garcia

INP-ENSIACET, LCA (Laboratoire de Chimie Agro-

Industrielle), INRA, UMR 1010 CAI, Université de Toulouse,

31030 Toulouse, France

\section{S. Jubeau}

Laboratoire GEPEA, CRTT, UMR CNRS 6144, Université de Nantes, 44602 Saint-Nazaire, France

\section{P. Michaud ( $\square)$}

Institut Pascal UMR CNRS 6602, Polytech' Clermont Ferrand, Clermont Université, Université Blaise Pascal, 24 Avenue des Landais, BP-20206, 63174 Aubière, France

e-mail: philippe.michaud@univ-bpclermont.fr

\section{Introduction}

Microalgae are unicellular and multicellular photosynthetic microorganisms from freshwater and marine systems that offer extremely interesting industrial potential. Definitions of microalgae include prokaryotic microalgae, i.e., cyanobacteria (Chloroxybacteria), and eukaryotic microalgae, i.e., diatoms (Bacillariophyta), green algae (Chlorophyta) and red algae (Rhodophyta). Eukaryotic microalgae are recognized as primitive plants and can be either autotrophic or heterotrophic. Autotrophic microalgae require only inorganic compounds such as $\mathrm{CO}_{2}, \mathrm{~N}, \mathrm{~S}, \mathrm{P}$, and light as an energy source for their growth and development. They convert captured solar energy into biomass (photosynthesis) with efficiencies that generally exceed those of terrestrial plants ( $3 \%$ reported for marine microalgae against $0.2-2 \%$ for terrestrial plants) [108]. Some photosynthetic microalgae are mixotrophic, meaning they are able to perform photosynthesis and to catabolize exogenous organic nutrients. For autotrophic microalgae, photosynthesis is essential to convert solar radiation and $\mathrm{CO}_{2}$ into reducing power, adenosine triphosphate (ATP), $\mathrm{O}_{2}$, and 3-phosphoglycerate, which are then used to support growth. With these simple growth requirements, microalgae can sustainably generate lipids, proteins, and carbohydrates at a large scale, offering promising environmentally friendly alternatives to the current consumer products. The most prominent examples are biofuels, human diet and animal feed supplements, and applications in the pharmaceutics, nutraceutics, and cosmetics industries. Some macroalgal compounds also show interesting functional properties (free radical scavengers) and could provide new treatments against diseases such as cancer or even AIDS [97]. However, these high-value compounds (primary products) are generally extracted individually through expensive processes that waste most of 
the microalgal material (co-products). The microalgae industry's future hinges on enabling first-generation biorefineries to valorize the main primary products from a biomass and not only one of them. In a schematic way, firstgeneration biorefineries work to a three-step concept highlighted in a schematic flowsheet shown in Fig. 1. These steps are disintegration of cells, fractionation of main component families, and purification of valuable biomolecules. Nevertheless, microalgal biorefineries are hard to set up due to the broad chemical and morphological diversity of microalgae and the high-value fractions that need to be obtained for specific applications. Indeed, each unit operation has to preserve the specific properties of the obtained fractions and the stability of the target compounds in the remaining materials. Given that the main molecular content groups are often associated with specific intracellular compartments, unit operations could be performed on a deconstructed biomass in a conceptual biorefinery (Fig. 2). These main families are lipids, polysaccharides, proteins, and pigments. Even though pigments are biochemically varied, they can be considered a single biochemical family for the purposes of a valorization strategy. All these

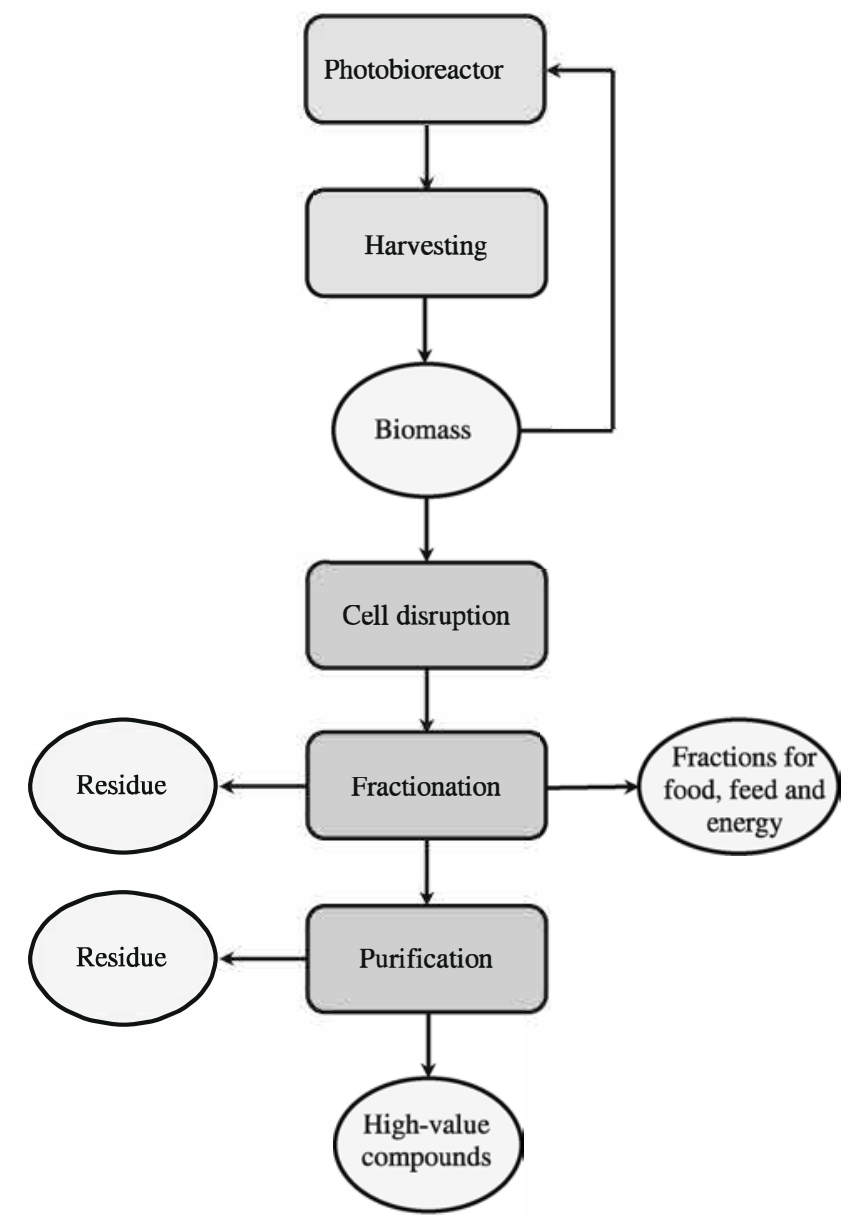

Fig. 1 A microalgae biorefinery compounds are qualitatively and quantitatively dependent on microalgal species used. However, some species have risen to prominence in the industry and are dedicated to specific applications due to their select biochemical composition. The aim of this review is to describe the biochemical composition and topology of selected microalgae and to highlight the compounds to be valorized in a firstgeneration biorefinery strategy.

\section{Lipids}

Biological lipids are chemically diverse groups that nevertheless share the common defining feature of being insoluble in water. Their biological functions, like their chemistry, are equally diverse. Oil-rich algae (called oleaginous species) can be grown either autotrophically and heterotrophically. In a biorefinery concept, this class of compounds, and more especially reserve lipids, are at the origin of biofuel production. Microalgae for biofuel production can be grown in several places all year round with significant advantages such as good oil productivity exceeding the yields of the best oilseed crops, non-use of arable land, low water consumption compared to crop irrigation, and low environmental impact [78]. Microalgae growing under normal conditions actually produce significant amounts of lipids, but this lipid accumulation decreases when cultivation conditions are optimized to increase biomass yield [76, 109, 124]. Microalgae contain primarily polar lipids such as phospholipids and glycolipids together with neutral storage lipids such as monoglycerides (MAGs), diglycerides (DAGs), and triglycerides (TAGs), free fatty acids, hydrocarbons, and pigments [57]. Polar lipids are confined to cell organelle membranes such as the thylakoid membranes of the chloroplast [57]. TAGs are neutral lipids mainly stored in vacuoles within the cell [21, 57]. Most microalgae accumulate very few TAGs during the exponential growth phase but can produce and store substantial amounts of TAGs during the stationary phase or under adverse environmental conditions [13, 57, 114]. Fatty acid (FA) composition may differ between lipid classes. As a rule, saturated fatty acids (SAFA) and monounsaturated fatty acids (MUFA) comprise the storage lipid fraction while polyunsaturated fatty acids (PUFA) largely comprise the structural lipid fraction [57]. However, culture processes and species selection have a major influence on lipid composition, accumulation, and distribution. For many microalgae, growth stressors such as excessive solar energy captured by photosynthesis, nitrogen depletion, salinity, or high temperature lead to primarily lipid storage, with high TAGs levels [26, 31, 62, 108,114 ] or to a shift in FA composition [38]. Some microalgae are well-known lipid producers extensively 
Fig. 2 Ultrastructure of microalgae: <Emphasis Type= Chlorophyceae, b Rodophyceae, and cyanobacteria (based on Ref. [70])
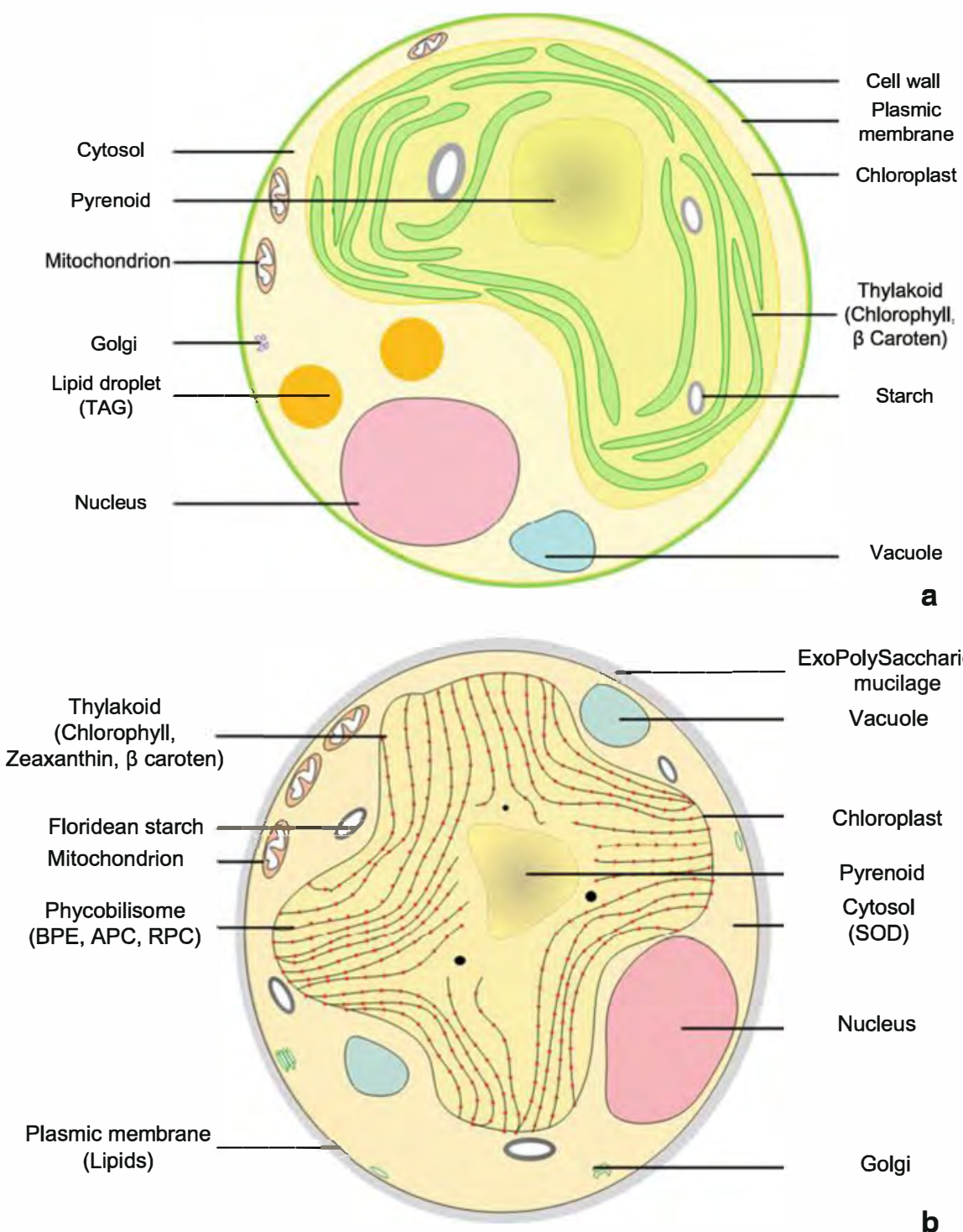

ExoPolySaccharides mucilage

Vacuole

Chloroplast

Pyrenoid

Cytosol

(SOD)

Nucleus

Golgi

b

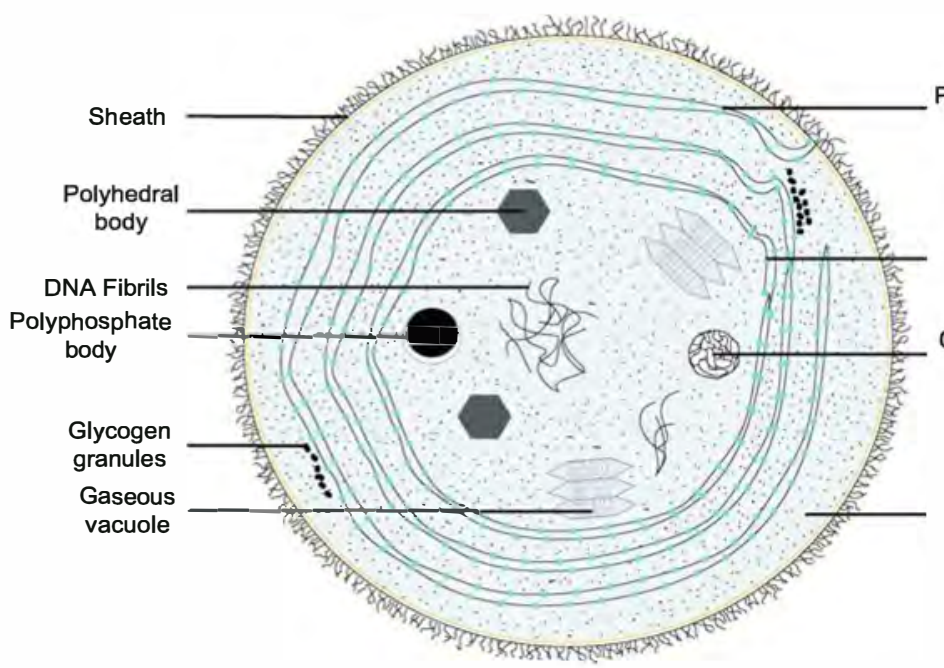

Phycobilisome

(PC)

Thylakoid

(Chlorophyll,

$\beta$ caroten)

Cyanophycin granules

Cytosol rich in ribosomes 
studied for biofuel and more especially for biodiesel production. Biodiesel is defined as monoalkyl esters of vegetable oils or animal fats. It is produced by the transesterification of TAGs with methanol (or other alcohols) in the presence of an appropriate catalyst, with glycerol as by-product. Biodiesel standards around the world, including the USA (ASTM D 6751) and Europe (EN 14214), also address storage and handling issueslinoleic and linolenic acid esters, for example, are prone to oxidation and so need to be chemically reduced by a hydrogenation process [63]. Hydrogenation converts double bonds to single bonds by $\mathrm{H}$ addition. Other microalgaeproducing lipids are exploited for food and feed applications, notably due to their unsaturated FA or pigment contents. A majority of the high-value lipid compounds extracted from these algae are long-chain PUFA and carotenoid pigments.

Although all microalgae are candidate lipid-producers, the "winners" for industry applications are the eukaryotic microalgae Chlorella vulgaris (up to $58 \% \mathrm{dw}$ ) [2], Nannachloropsis oculata (up to $69 \% \mathrm{dw}$ ) [19], Botryococcus braunii (up to $75 \% \mathrm{dw}$ ) [27], and Scenedesmus obliquus (up to $50 \% \mathrm{dw}$ ) [78]. Nonetheless, another eukaryotic microalgae such as Porphyridium cruentum may have futures for lipid-based industrial applications as they have original and/or highly specific lipid profiles, rich in longchain PUFA. Indeed, Porphyridium cruentum is rich in

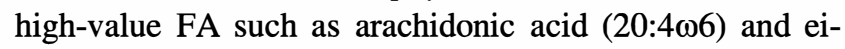
cosapentaenoic acid (20:5 33 ) [32] for a global lipid content of between 9 and $19 \%$ [78].

\section{Chlorella vulgaris}

Lipid accumulation as chloroplastic and cytoplasmic droplets by the green microalga $C$. vulgaris in freshwater (Fig. 2) requires a pre-extraction cell lysis step. Growth on nitrogen-limiting media resulted in higher lipid accumulation $(20-53 \%)$ but lower growth rate, whereas mixotrophic cultivation yielded higher lipid content (40-53\%) and higher lipid productivity (67-144 mg/l/day) in all culture media [124]. The FA composition of microalgal lipids comprises over 60-68 \% SAFA [124]. More specifically, the FA most accumulated are described as $\mathrm{C} 18$, C18:1, C18:2, and C18:3 (3.4, 16.3, and 79.4\% of total FA [68]. Choi et al. [30] compared the lipid production of mixotrophic and autotrophic cultures of Chlorella sp. Cultures were carried out in photobioreactors using various light periods and various $\mathrm{CO}_{2}$ supplementations [30]. Methanol (1 \% v/v) was used as sole organic carbon source in the mixotrophic conditions. The highest lipid accumulation $(18.6 \% \mathrm{dw}$ ) with high proportions of C16:0, C18:0, and $\mathrm{C} 18: 1$ was obtained with $5 \% \mathrm{CO}_{2}$ and $450 \mu \mathrm{E} / \mathrm{m}^{2} / \mathrm{s}$ of $12: 12$ (h) irradiation cycles in mixotrophic mode. It is interesting to note that in this study, mixotrophy gave better results than autotrophy. Previous data [30, 68, 124] suggest the lipid composition of $C$. vulgaris is suitable for biodiesel production. $C$. vulgaris was also grown in a column aeration photobioreactor filled with artificial wastewater in semicontinuous mode [41]. The highest lipid production and content were $147 \mathrm{mg} / \mathrm{l} / \mathrm{day}$ and $42 \% \mathrm{dw}$, respectively, in the optimal growth conditions, and the system was characterized as highly efficiency at removing nutrients from wastewater [41].

\section{Nannochloropsis oculata}

Nannochloropsis oculata is well known in marine biotechnology for its potential interest in biodiesel production. $N$. oculata NCTU-3 was grown in a semicontinuous system aerated with $2 \% \mathrm{CO}_{2}$ and operated by one-day replacement with the objective of optimizing culture for long-term biomass and lipid productions [28]. A two-stage cultivation strategy has also been proposed to enhance the lipid production of Nannochloropsis oculata [109]. Biomass growth and lipid production were experimented in two separate stages. Final lipid yield was 2.82-fold higher in these conditions than in traditional single-stage batch cultivation systems [109]. Microalgae lipid content was strongly influenced by the physical-chemical environment and composition of the culture media. For example, a temperature increase from 20 to $25{ }^{\circ} \mathrm{C}$ doubled the lipid content of N. oculata (from 7.90 to $14.92 \% \mathrm{dw}$ ), while a $75 \%$ decrease in nitrogen concentration in the medium increased $N$. oculata lipid content from 7.90 to $15.31 \%$ dw without impact on growth [33]. The authors identified high amounts of palmitic acid (16:0), which constituted about $60 \%$ (mol/ mol) of the overall lipid fraction, along with C18:1, C18:2, and $\mathrm{C} 18: 3$. This result confirmed the finding that storage lipids in Nannochloropsis sp. consist largely of the SAFA palmitic acid (C16:0) and the MUFA palmitoleic acid (C16:1) [110]. However, Tonon et al. [114] found that $68 \%$ of TAGs in Nannochloropsis oculata consisted of the PUFA eicosapentaenoic acid (20:5 $\omega 3$, EPA) at the end of stationary phase compared to just $8 \%$ in the exponential phase. Similarly, under nitrogen deprivation, the average biomass and lipid productivities of Nannochloropsis sp. reached 9.9 and $6.5 \mathrm{~g} / \mathrm{m}^{2} /$ day, respectively. Lipid content was $68.5 \%$ in starved biomass compared to $39.1 \%$ in nonstarved biomass, and the two cultivation conditions led to significant differences in lipid classes and FA composition [19]. Effectively, under nitrogen deprivation, polar lipid content decreased whereas neutral lipid content increased. The major lipids represented under nitrogen starvation were TAGs, polar lipids, and hydrocarbons (79, 9, and $2.5 \%$ of total lipids, respectively) [19]. The FA composition of the different lipid classes (neutral, polar, and 
phospholipids) includes mainly C16:0, C16:1, and C18:1. Note that polar lipids and phospholipids have a significant ratio of $\mathrm{C} 20: 5 \omega 3$ (eicosapentaenoic acid) in their structure. Lipid content, FA profiles, MAGs, DAGs, and TAGs were analyzed for 2 years in Nannochloropsis oculata biomasses grown outdoors in closed vertical flat-panel photobioreactors [88]. Results showed that the highest lipid content was recorded during autumn, signaling an optimal non-linear response to light and temperature. The authors hypothesized that enhanced thylakoid stacking under reduced light conditions resulted in more structural lipids concomitantly with the increase in glycerides due to released photo-oxidative stress. The relative increase in MUFA during autumn suggested a synthesis either of structural FA as MUFA or a relative increase of $\mathrm{C} 16: 1$ incorporated into TAGs and DAGs.

\section{Botryococcus braunii}

B. braunii is a colonial hydrocarbon-rich green microalga [6] widespread in freshwater and brackish lakes at temperate, tropical, and Arctic latitudes. B. braunii has tremendous potential as a renewable biomass feedstock and high potential for the production of renewable liquid hydrocarbons. The lipids of $B$. braunii can be repeatedly extracted from wet biomass without the usual harvesting and dewatering steps [18]. By exposing B. braunii to biocompatible organic solvent, a substantial fraction of hydrocarbons was obtained without impairing cell viability [42], as the majority of biosynthesized lipids in $B$. braunii are located in the outer cell wall of the algal material [18]. Note that a high percentage of hydrocarbons in some petroleum fuels were probably derived exclusively from this specie [122]. Depending on the type of hydrocarbons synthesized, B. braunii is classified into A, B, and L strains but some strains of this species are not classified [61]. For example, strain $B$. braunii AP103 grown on open raceway pond produced a biomass concentration of $1.8 \pm 0.13 \mathrm{~g} / \mathrm{l}$. Its biochemical analysis revealed $19 \%$ lipids, $33 \%$ carbohydrates, $18 \%$ proteins, and $11 \%$ hydrocarbons [4]. The hydrocarbon profile showed the presence of heptadecane $(34 \%)$ and hexadecane $(12.5 \%)$. The major FA detected in the lipids extracted were oleic $(25.7 \%)$, linolenic $(34.26 \%)$, and palmitic $(9.42 \%)$ acid [4]. B. braunii race $\mathrm{A}$ is a ubiquitous colonial green microalga that is an important synthesizer of lipids in fresh and brackish water ecosystems [82]. Race A produces C23-C33 odd-numbered $n$-alkadienes, mono-, tri-, tetra-, and pentanes from FA. Linear olefins can account for up to $61 \%$ of the dry matter of green active-state colonies. Note that the growth of $B$. braunii (race A) and its production of hydrocarbons and FA were influenced by environmental salinity [95]. The $\mathrm{L}$ race produces a single tetraterpene hydrocarbon called lycopadiene $\left(\mathrm{C}_{40} \mathrm{H}_{78}\right)$ and it accounts for up to 2-8 \% of dry biomass. The $\mathrm{B}$ race produces polyunsaturated and branched $\mathrm{C} 30-\mathrm{C} 37$ terpenoid hydrocarbons called polymethylated botryococcenes that are promising renewable energy sources as they accumulate at very high levels of $26-86 \%$ dry weight in the algae [82]. Photosynthesis, growth, and metabolic productivity of $B$. braunii BOT-22 cells (race B) were saturated at approximately $1,000,100$, and $200 \mu \mathrm{mol} / \mathrm{m}^{2} / \mathrm{s}$, respectively, under monochromatic red light. Lipid and hydrocarbon production was not directly supported by an increase in photosynthetic activity [102].

\section{Scenedesmus obliquus}

The green microalgae Scenedesmus obliquus is an oleaginous alga well known for its ability to accumulate lipids, notably in fresh wastewater [77]. The lipids of $S$. obliquus grown under controlled conditions have been characterized as $7.24 \%$ neutral lipid, $2.45 \%$ glycolipid and $1.48 \%$ phospholipid on a dry weight basis. The major neutral lipids were di- and triacylglycerol, free and esterified sterols, and hydrocarbons. The glycolipids were monogalactosyl diglyceride, digalactosyl diglyceride, free and esterified sterol glycoside. The phospholipids included phosphatidyl ethanolamine, phosphatidyl glycerol and phosphatidyl choline. The 14 FA identified in the lipid fractions were led by C18:2, C16:0, C18:3(alpha), C18:1, $\mathrm{C} 16: 3$, C16:1, and C16:4. Unsaturated and essential FA were quantified at 80 and $38 \%$ of total algal lipids, respectively [29]. The C16/C18 FA groups of $S$. obliquus lipids obtained from cultivation under nitrogen-starved conditions could reach up to $92.4 \%$ of total FA [56]. Oleic acid, an important indicator of biodiesel quality, accounted for $35.10 \%$ of total FA. The main FA of $S$. obliquus cultivated in nutrient-rich media with $10 \% \mathrm{CO}_{2}$ were $\mathrm{C} 16: 0$ (15-16\%), C16:1 (2-3\%), C18:0 (17-18\%), C18:1 (15-16\%), C18:2 (13-14\%), C18:3 (3-4\%), and several minor component FA with a carbon number lower than C16 and higher than $\mathrm{C} 18[56,76]$. These data were confirmed by [119]. Note also that under P-deficiency and thiosulphate supplementation, the lipid content of $S$. obliquus increased up to $30 \%$ [76].

\section{Polysaccharides}

Polysaccharides are defined as polymers of monosaccharides linked by glycosidic bonds. As for other organisms, microalgae polysaccharides demonstrate strong structural variability and biological functions [97]. Based on their role in the microalgae physiology, they can be split in three classes: structural polysaccharides generally associated to 
cell walls, energy polysaccharides like starch, and polysaccharides implicated in cellular communication and recognition sites. Structural investigations into polysaccharides are complicated by the very broad diversity of their constitutive monosaccharides (pentoses and hexoses), non-sugar substituents (e.g., sulfate, acetate, or pyruvate) and glycosidic linkages. If we exclude starch, exopolysaccharides (also known as exopolymeric substances or exopolymers when associated to proteins) have gained significant attention in the published literature. This popularity is explained by their extractability, as these biopolymers are produced by microalgae in the extracellular medium without covalent linkages with cell walls. In some cases, it is difficult to distinguish these exopolysaccharides from the cell wall in which they are embedded (e.g., exopolysaccharides of Porphyridium sp.) [3]. Their physiological role is unclear, but some authors have hypothesized that they prevent desiccation [94] or offer a mechanical protection enabling the cells to develop in a range of environments [3]. Microalgal production of polysaccharide and especially exopolysaccharide (EPS) could be also one way to control photosynthetic activity. Algae colony formation is linked to polysaccharide production [113], which is catalyzed by various factors including $\mathrm{C} / \mathrm{N}$ ratio. Reports suggest glyoxylate, a stimulator of carbon metabolism, is able to inhibit photorespiration and increase photosynthesis in higher plants [87] and some cyanobacteria [14]. Adding glyoxylate to algae like Anabaena cylindrica [15] and Cyanospira capsulate [91] triggers an excess of carbon flux resulting in intracellular polysaccharide accumulation and soluble extracellular polysaccharide release. A culture study by Liu et al. [73] found that Scenedesmus obliquus supplemented with glyoxylate increased exopolysaccharide production.

In recent years, there has been of surge of interest in polysaccharide-producing bacteria, cyanobacteria, and microalgae for industrial applications. Effectively, EPSs are regarded as an abundant source of structurally diverse polysaccharides and some may possess unique properties for special applications. Excluding the EPSs from Porphyridium sp. [46] or Arthrospira platensis [116], which have been partially characterized, and starch (known as floridean starch) located in cytoplasm and chloroplasts, structural characterization data on microalga-produced polysaccharides remains scarce, even on cell-wall polysaccharides. Vilchez et al. [120] tried to document a global composition of microalgae and described mono- and oligosaccharides as mainly represented by trehalose, glucose, sucrose, and mannose but also polyols. Polysaccharides were more or less ignored, and the authors only gave a global composition for monosaccharides (glucose, galactose, xylose, methylxylose, and glucuronic acid).

\section{Chlorella vulgaris}

The most important substance in $C$. vulgaris for human health is a cell-wall $\beta$-(1,3)-glucan that has potential as an antitumor agent [85]. This class of polysaccharide is well known as an active immunostimulator, free radical scavenger, and reducer of blood lipids [66]. To our knowledge, the exopolysaccharides or other cell wall polymers from this microalgae have not been described. The only exception is an acidic polysaccharide containing high contents of glucuronic acid and rhamnose identified as a cell wall component [86].

\section{Arthrospira platensis}

Arthrospira platensis, (Spirulina) is a Gram-negative cyanobacteria species. A. platensis grows in tropical and subtropical waters with $\mathrm{pH}$ between 8 and 11 and high carbonate and bicarbonate concentrations. The EPS of $A$. platensis is generally considered as a polyanionic sulfated heteropolymer containing proteins, carbohydrates, and sulfated groups. Contents were estimated at 55, 13, and $0.5 \%$, respectively in A. platensis Compére 1968/3786 strain grown in photoautotrophic-mode for 25 days. Carbohydrates are mainly composed of seven neutral sugars [galactose $(14.9 \%)$, xylose $(14.3 \%)$, glucose $(13.2 \%)$, fructose $(13.2 \%)$, rhamnose $(3.7 \%)$, arabinose $(1 \%)$, mannose $(0.3 \%)$ ], and two uronic acids [galacturonic and glucuronic acids; $13.5 \%$ together] [116]. Trabelsi et al. [115] evaluated EPS production in relation to culture mode: high EPS levels were obtained in culture medium using mixotrophy with a short cultivation period whereas photoautotropohy and heterotrophy cultures produced low EPS levels at longer cultivation periods $(290 ; 219$ and $30 \mathrm{mg} / \mathrm{l}$, respectively; $1.5 \mathrm{~g} / \mathrm{l}$ glucose and/or $100 \mu \mathrm{mol}$ photon $\mathrm{m}^{-2} \mathrm{~s}^{-1}$ ). Optimizing light and glucose concentrations led to a peak production level of $369 \mathrm{mg}$ EPS/l in mixotrophic mode.

EPS from A. platensis exhibits interesting functional properties. It has value to industry due a non-Newtonian pseudoplastic behavior, but the main applications remain pharmaceutical in nature due to its wide range of biological properties. The sulfated EPS from A. platensis acts as anticoagulant, anti-thrombogenic and anti-atherogenic [97]. In addition, calcium and sodium spirulans isolated from hot water-extracted EPS interfere with the adsorption and penetration of viruses like herpes or HIV [55]. Challouf et al. [25] ran cytotoxicity and antioxidant assays on solvent-isolated EPS and concluded that its biological activity is closely tied to the molecular weight and conformation of EPS in terms of solvent-polymer interactions and the presence of sulfated moieties. 


\section{Botryococcus braunii}

Race-A and race-B strains produce EPS at up to $250 \mathrm{~g} / \mathrm{m}^{3}$ whereas L-race strains produce EPS at up to $1 \mathrm{~kg} / \mathrm{m}^{3}[6]$. However, EPS production level varies with strain and culture conditions such as culture media, illumination, agitation, and above all salinity $[35,36,95]$. B. braunii appears to produce carbohydrates as an osmoprotectant. The authors failed to describe the structures of these exopolymers and only quantified them after ethanol precipitation of culture medium supernatant and/or phenolsulfuric assay [35, 36, 95].

\section{Dunaliella salina}

Dunaliella salina is a type of halophile pink microalgae especially found in sea salt fields. EPS production by this strain increases with salt concentration in the culture medium, and peak production $(944 \mathrm{mg} / \mathrm{l})$ was obtained at $5 \mathrm{M} \mathrm{NaCl}$ [83]. Isolated EPS showing emulsifying activity slightly reduces with salinity. ${ }^{1} \mathrm{H}$ NMR, FT-IR, and HPLC have given structural clues on the presence of uronic acids, halides, sulfides, alkyl amine, and/or cyclic amine with polysaccharides. Galactose, glucose, xylose, and fructose were detected as constitutive monosaccharides [83]. Finegrained monosaccharide composition analysis in five fractions of a polysaccharidic crude extract fractionated by DEAE chromatography using reverse-phase HPLC showed that PD1 and PD4a fractions were acidic heteropolysaccharides mainly containing glucose and galactose, respectively, and that PD4a contained sulfated groups. PD2 and PD3 were identified as a glucan. PD4b was a complex of polysaccharide covalently linked with nucleic acids. Compositional analysis of PD4a confirmed the deduction made by Fabregas et al. [39] that water extracts with antivirus activity from $D$. salina contained sulfated polysaccharides with a molecular weight of a hundred-thousand $\mathrm{Da}$ [34]. These EPS proved thermostable up to $270{ }^{\circ} \mathrm{C}$ and their dynamic viscosity was significantly high at $\mathrm{pH} 3.0$ but decreased with shear rate, confirming pseudoplastic rheological properties [83].

\section{Porphyridium sp.}

Porphyridium sp. is a red marine microalga (Rodophyta) with spherical cells whose cell walls lack cellulose microfibrillar components. These microalgae are encapsulated within a sulfated polysaccharide gel (red microalgae cell wall). During growth, the outer gel dissolves in the growth medium while $50-70 \%$ of the polysaccharide stays attached to the cell [106], forming an outer layer that shields the microalgae against extreme environment conditions (e.g., desiccation or salinity). The polysaccharides

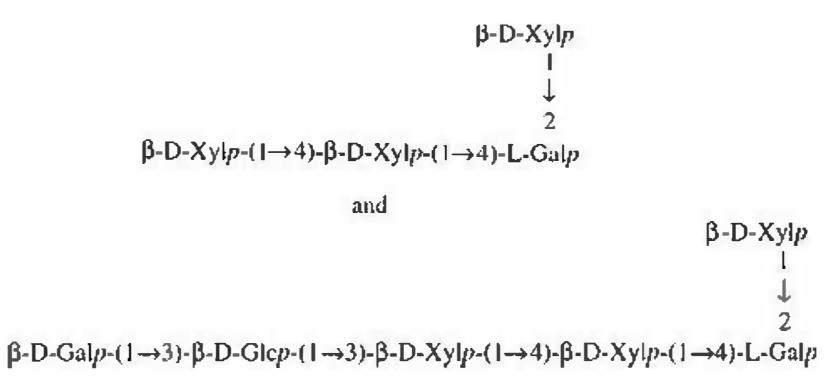

Fig. 3 Structures of oligosaccharides isolated from the exopolymeric fraction of Porphyridium sp. [46]

have a molecular weight in the range $2-7 \times 10^{6} \mathrm{Da}$ and are negatively charged due to the presence of glucuronic acid and sulfate groups. They are composed of up to ten monosaccharides, the most abundant being xylose, glucose, and galactose. Note that proteins represent $5.5 \%$ of polymer dw. The structure of EPS from Porphyridium sp. was partially characterized by Gloagen et al. [46] with oligosaccharides obtained after polysaccharide degradation by lithium (Fig. 3). This polysaccharide has various concrete applications in the cosmetics, drugs, crop growth promoters, and health food markets. A feature of these EPSs is their fluid-dynamic behavior that gives highly viscous solutions at relatively low polymer concentrations in a wide range of $\mathrm{pH}$ and temperature values, yielding comparable rheological properties to industrial polysaccharides [3, 89]. Sun et al. [111] tested the antioxidant activity of degraded (microwave) polysaccharides from $P$. cruentum and found that smaller-sized polysaccharides have a better antioxidant effect. It was also shown that these polysaccharides exhibit antiviral (anti-herpes) and antitumor activities [106, 112].

\section{Pigments}

Pigments are complex molecules or macromolecules that have the ability to change the color of reflected or transmitted light as a result of wavelength-selective absorption. Chlorophylls are green pigments with polycyclic planar structures esterified by a long phytol side-chain where $\mathrm{Mg}^{2+}$ occupies the central position. The chlorophylls differ by the substituents on their ring. The chlorophylls identified in microalgae are a, b, and c and are located in the thylakoids of chloroplasts [69]. Depending on microalgae species, some chlorophylls are not always present in photosynthetic structures. Cyanobacteria and red algae employ phycobylins such as phycoerythrobilins and phycocyanobilins [9]. These open-chain tetrapyrols have the polyene system of chlorophylls but not their cyclic structure or central $\mathrm{Mg}^{2+}$. They are covalently linked to specific proteins, forming phycobiliproteins. Phycobiliproteins are 
associated in order complexes called phycobilisomes. Phycobilisomes are the primary light-harvesting structures of these microorganisms and are attached in regular arrays to the outer surface of the thylakoids [8]. Phycobilisomes absorb light over a wide range of wavelengths and transfer the energy to the reaction centers in the photosynthetic membranes for conversion into chemical energy [16]. In addition to chlorophylls, thylakoid membranes contain accessory photosynthetic pigments called carotenoids. Carotenoids are a class of hydrocarbons (carotenes) and their oxygenated derivatives (xanthophylls) consist of eight isoprenoid units (Fig. 4). Carotenoids may be purple, yellow, or red. The accumulation of secondary carotenoids is generally thought to be a survival strategy employed by the algae under photo-oxidative stress or other adverse environmental conditions [58]. The most important are redorange $\beta$-carotene, an isoprenoid, and the yellow lutein. This section focuses on xanthophylls and phycobiliproteins, which are high-value compounds for industrial applications. Among the microorganisms detailed for these molecular families in the literature, the following eukaryotic microalgae emerge as the most significant: Chlorella vulgaris, Dunaliella salina, Haematococcus pluvialis,
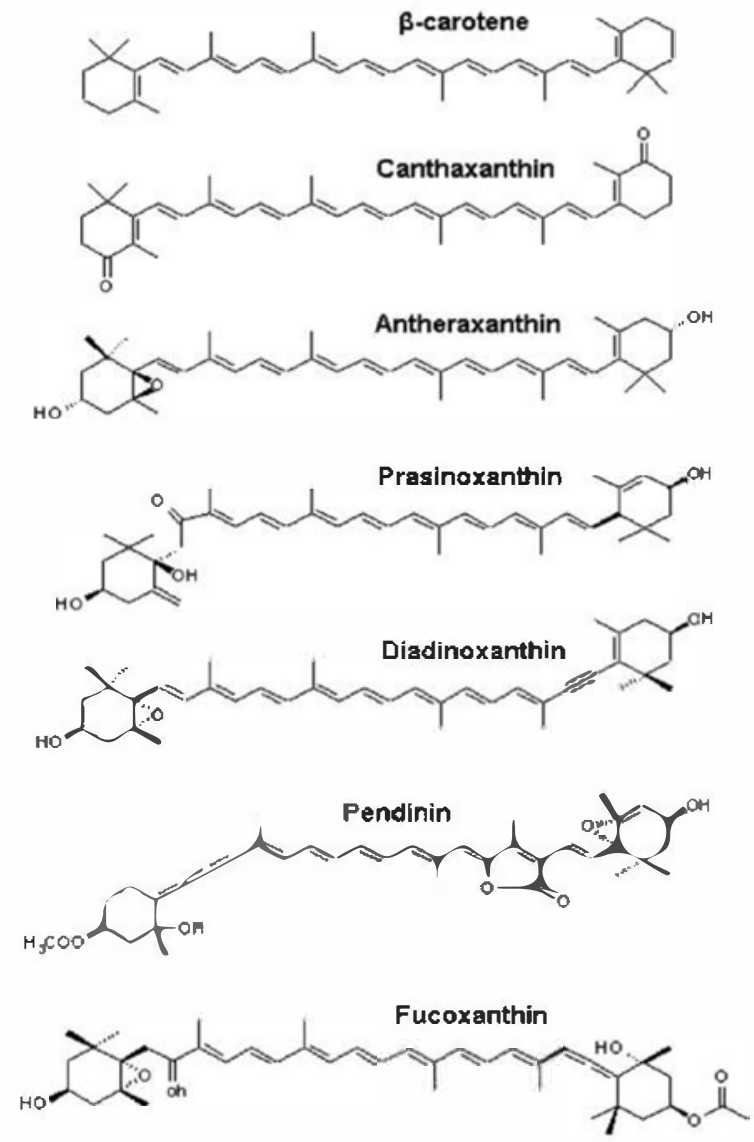

Porphyridium cruentum, Arthrospira platensis, and Haslea ostrearia.

\section{Chlorella vulgaris}

Like other species of microalgae, $C$. vulgaris is able to activate metabolic pathways and accumulate carotenoids in response to high irradiance stresses, nitrogen availability, and other changes in environmental conditions. Gouveia et al. [50] studied carotenoid biosynthesis by $C$. vulgaris grown in a reactor for 22 days under a light intensity of 38/ $\mu \mathrm{E} / \mathrm{s} / \mathrm{m}^{2}$, saline stress $(30 \mathrm{~g} / \mathrm{l} \mathrm{NaCl})$, and nitrogen starvation. They observed that $\beta$-carotene and lutein were first biosynthesized along with chlorophyll- $a$ during the exponential phase. Carotenogenesis was activated just before the stationary phase, and $\beta$-carotene and lutein concentrations decreased while canthaxanthin, astaxanthin, and astaxanthin esters were biosynthesized in stressed cells. It was suggested that the accumulation of canthaxanthin resulted from the oxidative transformation of $\beta$-carotene and that hydroxylated/oxidized astaxanthin was biosynthesized from zeaxanthin/lutein precursors towards hydroxylative pathways. Lutein and $\beta$-carotene content in<smiles>CC1=CC(O)CC(C)(C)[C@H]1/C=C/C(C)=C/C=C/C=C/C=C/C=C(C)/C=C/C=C(C)/C=C/C1=C(C)C[C@@H](O)CC1(C)C</smiles>

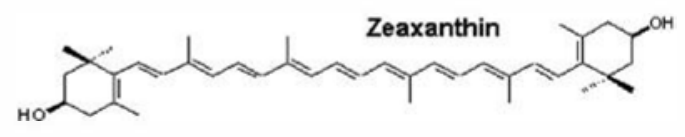<smiles>CC(/C=C/C=C/C=C(C)/C=C/C12OC1(C)CC(O)CC2(C)C)=C\C=C\C(C)=C\C=C\C(C)=C\C=C\C1(C)C(C)(C)CC(O)CC1(C)C</smiles>

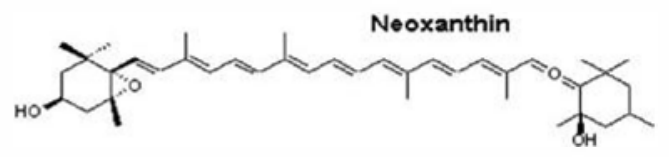<smiles>CC(C#CC1=CCC(O)CC1(C)C)=CC=CC(C)=CC=CC=C(C)C=CC=CC(C)=CC=CC1=C(C)CC(O)CC1(C)C</smiles><smiles>CCCCCCCCCCCCCCCC=CC(C)=CC=CC=CC(C)=CC=CC=C(C)C=CC1=C(C)C(=O)C(O)CC1(C)C</smiles><smiles>CC(C#CC1=C(C)C[C@H](O)CC1(C)C)=C/C=C/C=C(C)/C=C/C=C/C=C(C)/C=C/C=C(\C)C#CC1=C(C)C[C@@H](C)CC1(C)C</smiles>

Fig. 4 Structure of the main microalgal carotenoids [43] 
"green" $C$. vulgaris grown under normal conditions is about 8 and $5 \mathrm{mg} / 100 \mathrm{~g}$, respectively [24, 100]. Nevertheless, Mendes et al. [79] extracted pigments of "orange" C. vulgaris obtained from a carotenogenesis-optimized culture. Supercritical $\mathrm{CO}_{2}$ extraction was estimated to be efficient at removing carotenoids from well-crushed biomass (content: $547 \mathrm{mg} / 100 \mathrm{~g} \mathrm{dw}$ ) compared to solvent (acetone) extraction (content: $133 \mathrm{mg} / 100 \mathrm{~g} \mathrm{dw}$ ). Astaxanthin and canthaxanthin composed $2 / 3$ of the extracted carotenoids [80]. However, carotenoid content is straindependent. Ruen-ngam et al. [100] estimated the lutein content from spray-dried high lutein content $C$. vulgaris to be $7.9 \mathrm{mg} / \mathrm{g} \mathrm{dw}$. Carotenoids from $C$. vulgaris have important pharmaceutical and food-industry applications. Indeed, semi-purified carotenoid (mainly lutein) extracts showed antiproliferative activity in an MTT assay on HCT116 cells with interesting $\mathrm{IC}_{50}$ values [24]. Carotenoids from $C$. vulgaris have also been tested for their coloring and antioxidant properties in egg yolk, fish, food emulsions, and soybean oil $[49,50]$.

\section{Arthrospira platensis}

C-phycocyanin is the major phycobiliprotein of the cyanobacterium A. platensis (also known as Spirulina platensis). This bright-blue pigment is part of the phycobilisome and is used for photosynthetic light collection and transfer of chemical energy to the photosynthetic apparatus. C-phycocyanin has an estimated molecular weight of $100-200 \mathrm{kDa}$ according to filtration techniques [60]. It is formed of two sub-units $\alpha$ and $\beta$ with molecular weights of 20.5 and $23.5 \mathrm{kDa}$, respectively [8]. A. platentis has a chemical composition that shows promising effects on human and animal health. Indeed, the whole alga is used as nutrient ingredients, and C-phycocyanin is used as natural dyes for food and cosmetics. C-phycocyanin also shows promise as a potential therapeutic agent for oxidative stress-induced diseases and as a fluorescent marker for biomedical research. C-phycocyanin content could reach $20 \%$ [103]. However, A. platensis does contain other phycobiliproteins: Patel et al. [90] determined C-phycocyanin, allophycocyanins, and phycoerythrin contents to be $17.5,3.8$, and $1.2 \% \mathrm{dw}$, respectively. A. platensis is also rich in carotenoids, $80 \%$ of which are $\beta$-carotenes, the rest being physoxanthin and cryptoxanthin. The $\beta$-carotene and cryptoxanthin contents are very low under normal growth conditions (just 0.2 and $0.01 \% \mathrm{dw}$, respectively) but these two carotenoids warrant mention as they are both convertible to vitamin A by mammals [22]. Abd El-Baky et al. [1] studied the influence of nitrogen and $\mathrm{NaCl}$ concentrations on A. platensis growth in batch culture and found that cyanobacterium responded to nitrogen starvation and high $\mathrm{NaCl}$ levels by accumulating carotenoids. High carotenoid contents were obtained when $A$. platensis was grown at a low nitrogen level (51 ppm $\mathrm{N}$ ), with values ranging from 19.82 to $24.1 \mathrm{mg} / \mathrm{g}(\mathrm{dw})$.

\section{Haematococcus pluvialis and Haematococcus sp.}

Haematococcus pluvialis is a freshwater unicellular green eukaryotic microalgae belonging to the class Chlorophyceae. It can grow under autotrophic or heterotrophic conditions and is commercially well known for its ability to produce massive amounts of astaxanthin (3,3'-dihydroxy$\beta, \beta$-carotene- $4,4^{\prime}$-dione), a red ketocarotenoid accumulated at up to $2.0 \%(\mathrm{dw})$. Astaxanthin is biosynthesized through the isoprenoid pathway [51]. It is a high-value product for pharmaceutical, nutraceutical and animal nutrition applications [74]. Astaxanthin from Haematococcus algae is under consideration for clearance by the US FDA and has already been cleared for sale in several European countries as a dietary supplement ingredient for human consumption. $H$. pluvialis changes from a motile, flagellated cell to a non-motile, thick-walled aplanospore during the growth cycle [20,64]. The astaxanthin is contained in the aplanospore. Astaxanthin content in the aplanospores is about $1-2 \%$ of $\mathrm{dw}$, and the thick wall requires physical breakage before the astaxanthin can be either extracted or made available to organisms consuming the alga [81, 107]. Zhekisheva et al. [125] suggested that astaxanthin accumulation under a monoesterified form under high light or nitrogen starvations was linked with FA accumulation. In both cases, the newly formed FA mostly correspond to oleic acid. The production of oleic acid-rich triacylglycerols and the esterification of astaxantin enable the oil globules to maintain a high content of astaxantin esters. The highest rate of carotenoid biosynthesis was observed almost simultaneously with the highest rates of cell division and chlorophyll biosynthesis after exposure to limited nitrogen and high irradiance [54]. A photo-protective role for astaxanthin has been suggested based on comparisons of astaxanthin-rich cells with astaxanthin-free vegetative cells, along with lower lipid peroxidation [53], a higher Fv/ Fm value [52], or a higher oxygen evolution rate [54, 121].

\section{Dunaliella salina and Dunaliella sp.}

When the halophilic eukaryotic microalgae $D$. salina is under appropriate (carotenogenic) cultivation conditions, it produces more than $10 \%$ (on a dw basis) $\beta$-carotene versus just $0.3 \%$ for other microalgae and higher plants. This massive accumulation of $\beta$-carotene seems to be a protection mechanism to counteract the negative effects of solar radiations [44, 123]. High $\beta$-carotene content makes the cell display bright red coloration owing to the characteristic absorption spectrum of $\beta$-carotene. Dunaliella 
species concentrate $\beta$-carotene in the interthylakoid spaces of the cell's single chloroplast in the form of lipid globules under carotenogenic conditions. Few or no globules exist when the cell is cultivated under non-induced conditions [12]. One analysis found that this membrane-free lipid globule was exclusively composed of $\beta$-carotene (more than half), neutral lipids (mainly with triacylglycerols) and a small amount of protein [12].

\section{Porphyridium sp.}

The main accessory light-harvesting complexes of Porphyridium cruentum are phycobilisomes. $P$. cruentum phycobilisomes are described as hemiellipsoidal, containing a tricylindrical core subassembly in the semi-spherical centre and several peripheral rods radiating out from the center to form the rounded surface of the semi-sphere. The core contains allophycocyanins, while the peripheral rods are mainly composed of phycocyanins and phycoerythrins. It has been shown that $P$. purpureum ( $P$. cruentum) contains four phycobiliproteins: allophycocyanins (5\%), R-phycocyanin (11\%), b-phycoerythrin (42\%), and B-phycoerythrin (42\%) [17]. Porphyridium sp. is the potential organism for the production of phycoerythrins and especially B-phycoerythrin. B-phycoerythrin is the major light-harvesting pigment and the most valuable of the three main phycoerythrins classes due to its high fluorescence efficiency (intense unique pink color) and therapeutic value (immunomodulatory and anticarcinogenic activity). Rebolloso-Fuentes et al. [98] studied the influence of dilution rates, residence time, and solar irradiation conditions on the biomass profiles of $P$. cruentum grown on outdoor photobioreactor systems. The authors reported peak values of $3.6 \% \mathrm{dw}$ PB and $2.8 \%$ dw phycoerythrins, but allophycocyanins and phycocyanin were also detected at up to 0.36 and $0.43 \% \mathrm{dw}$, respectively. It has also been demonstrated in $P$. purpureum that phycoerythrin production is dependent on salt concentration in the culture medium. Sodium chloride seems to possess the maximum effect, and it was established that PB and phycoerythrins production can reach over 4.8 and $3.3 \% \mathrm{dw}$, respectively, under optimal cultivation conditions at lab scale. Further optimization of specific culture parameters (light and sodium bicarbonate concentration) of a culture of $P$. purpureum led to a pigment-rich content composed of B-phycoerythrin (12.17\% dw), R-phycocyanin (10.2\% $\mathrm{dw})$, and allophycocyanins $(2.0 \% \mathrm{dw})$ [118].

\section{Haslea ostrearia}

Haslea ostrearia, previously known as Navicula ostrearia, is a diatom involved in the greening of the French oysters called "Fines de Claires" [65]. This microalga synthesizes a blue-green water-soluble pigment called marennine that is first stored at the apex of the cells then released into the surrounding environment [96]. Marennine is present under two different location-specific forms: extracellular marennine (EMn; molecular weight: 9,893 Da) and intracellular marennine (IMn; molecular weight: 10,751 Da) [92]. Although the structure of the molecule remains unknown, Pouvreau et al. [92] have shown that it is a polyphenolic compound close to the proanthocyanides. The specific absorption coefficients of purified EMn and IMn were $12.13 \mathrm{l} / \mathrm{g} / \mathrm{cm}$ at $677 \mathrm{~nm}$ and $6.88 \mathrm{1} / \mathrm{g} / \mathrm{cm}$ at $672 \mathrm{~nm}$, respectively. This pigment is not involved in photosynthesis processes but instead acts as a photoprotector that is produced in response to different stresses such as high light intensity [84] or nitrogen and silica depletion [84, 99]. Marennine possesses antiproliferative, antiviral, and photoprotective activities [45, 93].

\section{Proteins}

Proteins constitute a large fraction of the actively growing eukaryotic microalgae and cyanobacteria. They are generally undervalued compared to minor products such as unsaturated FA or pigments for medical, pharmaceutical, and nutraceutical applications. Today, there are still no significant applications of purified proteins from microalgae, since the presence of non-protein components generally leads to undesired changes in color, taste, and protein structure [104]. Nevertheless, efforts are now turning to the impressive genetic potential of microalgae on one hand and the specific activities of microalgal proteins on the other. However, some algal biomasses are often used directly as a supplement in human diet, animal feed, or aquaculture, largely due to their high protein levels.

\section{Chlorella vulgaris}

C. vulgaris cultures grown in semicontinuous photobioreactor mode under constant irradiance contained up to $58 \%$ protein content [10]. Seyfabadi et al. [105] studied the effects of irradiance and photoperiod on the total FA, pigment and protein contents of $C$. vulgaris. Total protein was then estimated to be $46 \%$ at $100 \mu \mathrm{mol}$ photons $/ \mathrm{m}^{2} / \mathrm{s}$ and $16: 8 \mathrm{~h}$ photoperiod. Mahboob et al. [75] determined the biochemical composition of a thermotolerant strain of $C$. vulgaris grown in mixotrophic mode with the aim of determining the biological value of the biomass for further aquaculture applications. Crude protein production was $2.26 \mathrm{~g} / \mathrm{l} / \mathrm{d}$ with urea as nitrogen source, and maximum protein content was $60 \% \mathrm{dw}$. The crude protein extracts contained 17 amino acids, including the essential amino acids (AA) isoleucine, leucine, lysine, methionine, phenylalanine, and valine. 
Comparative analysis against FAO/WAO requirements for aquaculture development was performed based on AA and essential AA profile. It was confirmed that the thermotolerant C. vulgaris grown under mixotrophic mode is suitable for aquaculture applications. In addition, the high scores obtained for lysine and threonine suggested that this biomass may be utilized as a feed supplement in grain-based diets. Janczyk et al. [59] tested the nutritional quality of pretreated (cell lysis) C. vulgaris on growing Wistar rats. Note that the pretreatment was necessary to degrade the rigid cellulosic cell wall, which is not digestible for humans and other nonruminants, and to make the intracellular compounds accessible. Animals were fed with the algal products as sole protein source (150 mg N per $100 \mathrm{~g}$ of bw), and digestion coefficient, net protein utilization, biological value, and protein efficiency ratio (PER) were recorded. Ultrasonication emerged as the best pretreatment, with digestion coefficient, biological value and protein efficiency ratio values of 64,101 , and 2.1 , respectively. Protein digestibility was close to $70 \%$. Comparable results were obtained by Becker [10] on drum-dried Chlorella sp. with maximum values for digestibility, biological value, net protein utilization, and protein efficiency ratio of $89,77,68$, and 2.00 , respectively, highlighting that the pretreated biomass was of good nutritive quality.

\section{Arthrospira platensis}

A. platensis is considered an alternative protein source and a very promising food supplement or additive, as its biomass contains up to $70 \% \mathrm{dw}$ of proteins [5]. The quality of powders from $A$. platensis (drum-dried and sun-dried biomasses) was assessed using parameters representative of nutritional quality. Maximum digestion coefficient, net protein utilization, biological value, and protein efficiency ratio values were $77.6,83.9,65.0$, and 2.10 , respectively. These values are relatively close to those of reference nutrition proteins such as casein or egg proteins, highlighting the quality of $A$. platensis as protein source for human nutrition or as a feed supplement [10]. Additional data indicate that proteins from A. platensis are up to $90 \%$ digestible and contain about $60 \%$ essential AA [37]. Depleted culture media have a significant impact on the protein content of $A$. platensis. In a study on batch cultures systems, the crude protein content of $S$. platensis harvested at the stationary phase was $67.4,53.5$, and $5.6 \% \mathrm{dw}$ for controls, $50 \%$-nitrogen-depleted media and $100 \%$-nitrogen-depleted media, respectively [117].

\section{Scenedesmus obliquus}

$S$. obliquus is commonly used for biofuel production but is also important as a source of proteins, with maximum content reaching $56 \%$ [10]. However, many authors have described $S$. obliquus as a good candidate for wastewater treatment and the conversion of nutrients or waste compounds to biomass. The protein content of $S$. obliquus grown in outdoor conditions in artificial wastewater during 3 days under seasonal irradiance levels was ranged from $33.5-38 \% \mathrm{dw}$ in winter to $51 \% \mathrm{dw}$ in summer [47]. Çelekli and Balci [23] evaluated the production of proteins from Scenedesmus sp. grown in Johnson's medium as a function of $\mathrm{P}$ and $\mathrm{N}$ concentration in the culture medium, and found that protein production was strongly related to nutrient concentration. Maximum protein yield was $32 \mathrm{mg} / \mathrm{l}$ for $0.3 \mathrm{mM} P$ and $12 \mathrm{mM} \mathrm{N}$. In another experiment, RuizMartin et al. [101] showed that a semicontinuous culture of immobilized $S$. obliquus did not appear to allow sustainable culture for wastewater treatment compared to a free-cell culture. Protein content first increased but then tailed off toward the end of the treatment $(250 \mathrm{~h})$, meaning that the exponential phase was maintained for a few cycles before the culture collapsed. However, protein content hit a peak of $30 \% \mathrm{dw}$ compared to only $16 \% \mathrm{dw}$ in the free-cell culture. The immobilized system thus appears suitable for separating biomass from wastewater whereas the free-cell system appears to be the best option for producing biomasses with high nutritional potential. This nutritional quality of $S$. obliquus was confirmed by the maximum biological value, digestion coefficient, net protein utilization, and protein efficiency ratio values $(75.0,88.0,67.3$, and 1.99 , respectively) and the essential AA content that ranged from 30 to $45 \%$ of total AA. It was concluded that low concentrations of metallic pollutants stimulated the production of biomass and improved total protein content and AA biosynthesis whereas high concentrations were inhibitory [10].

\section{Dunaliella sp.}

The marine microalgae $D$. salina is mainly identified as a carotenoid producer, and is widely used in cosmetics. There has been little research on the nutritional, functional, and biological properties of the proteins but intensive research on their specific role in the mechanisms of salt tolerance. Certain specific proteins (e.g., two membranebound proteins: a $60-\mathrm{kDa}$ carbonic anhydrase and a 150-kDa transferrin-like protein) and enzymes (e.g., dihydroxy acetone reductase reduction of dihydroxyacetone in glycerol) can be induced by different salinities in the osmotic response processes [72]. More, Dunaliella sp. is amenable for genetic manipulation and is a good candidate for the induction, accumulation and production of several novel bioactive compounds, including valuable enzymes. For instance, dihydroxy acetone reductase has been obtained from $D$. salina at the industrial scale and subsequently produced for commercialization [11]. 


\section{Porphyridium sp.}

$P$. cruentum is not necessarily known for its nutritional value despite its rich FA composition (eicosapentaenoic acid, docosahexaenoic acid, etc.) and significant protein content (up to $35 \%$ ) [48], which includes a significant fraction of phycobiliproteins, EPS-embedded proteins, biological membrane or cell wall proteins, and free proteins, but more crucially, superoxide dismutase. Superoxide dismutase is a free cytoplasmic enzyme that is synthesized in abundance and considered a high-value compound for biomedical applications such as the treatment of cancers or HIV involving free radicals and other active forms of oxygen [7]. Moreover, among the proteins of the EPS cell wall of Porphyridium sp., the most prominent is a $66-\mathrm{kDa}$ glycoprotein (consisting of a $58-\mathrm{kDa}$ polypeptide and $8-\mathrm{kDa}$ sugar moieties) that is tightly bound but not covalently linked to EPSs. This glycoprotein merits attention due to its role in biorecognition and its potential biotechnological applications such as for understanding the $\mathrm{N}$-glycosylation mechanisms linked to the production of therapeutic proteins, where the algae could be used as a "cell factory" [71].

\section{Tetraselmis suecica}

Tetraselmis suecica, a marine green microalgae, is widely used as a source of nutrients for invertebrates in aquaculture due to its homogenous chemical composition and high protein content ranging from 26 to $69 \% \mathrm{dw}$, depending on growth conditions [40]. Bondioli et al. [19] recorded a substantial decrease in protein content when $T$. suecica was grown in semicontinuous-mode in outdoor "green wall panels" under both $\mathrm{N}$ and $\mathrm{P}$ starvation. Indeed, the protein content of $\mathrm{N}$-sufficient, $\mathrm{N}$-starved, and $\mathrm{N}$-and-P-starved $T$. suecica were 52,8 , and $9 \% \mathrm{dw}$, respectively, in 14-day cultures. Nevertheless, Laws et al. [67], studying the relationship between growth rate and biochemical composition, concluded that the control of $T$. suecica growth rate in a continuous-mode system and phosphate-limited conditions is a convenient way to optimize the biochemical composition of $T$. suecica and its nutritional value to invertebrate consumers in aquaculture systems. Protein content under this protocol was estimated to range from a minimum of $7 \%$ at zero growth rate to a maximum of $59 \%$ at a relative growth rate of 1.0 .

\section{Conclusions}

The past two decades have seen huge strides forward in our understanding of the chemical composition, cellular compartments, and culture conditions of eukaryotic microalgae and cyanobacteria, culminating in the development of new-generation photobioreactors enabling large-scale microalgae biomass farming. Moreover, the recent industry drive for microalgae applications in the near future, mainly for biodiesel production but also for more specific applications in the fields of food, feed, cosmetics, and therapeutics, has prompted a significant increase in funding for this field of science. However, the fractionation of all components of microalgae biomasses under a biorefinery framework is an emergent concept that starts to be translated into real-world industrial practice. The complexity of membrane bound organelles, granules, and droplets containing specific biomolecule classes combined with inadequate methods for separating them has meant that in many cases, only a single biomolecular fraction extracted from specific species actually gets used. A biorefinery approach generally entails upgrading spent biomass after lipid extraction at the expense of alternative bulk or fine chemical production streams. Some breakthroughs are still needed in the design and development of technologies that can reduce costs and increase yields, but even more important is the development of a methodology and technical processes for the global utilization of microalgae. The strategy can be considered as the eco-design of an integrated production scheme. Integrated studies will probably attain the goal of using lipid-producing strains under adapted growth conditions and optimized processes to successfully create an economically viable biorefinery of microalgae.

\section{References}

1. Abd El-Baky HH, El Baz FK, El-Baroty GS (2003) Spirulina species as a source of carotenoids and $\alpha$-tocopherol and its anticarcinoma factors. Biotechnology 2:222-240

2. Amaro HM, Guedes AC, Malcata FX (2011) Advances and perspectives in using microalgae to produce biodiesel. Appl Energy 88:3402-3410

3. Arad SM, Levy-Ontman O (2010) Red microalgal cell-wall polysaccharides: biotechnological aspects. Curr Opin Biotechnol 21:358-364

4. Ashokkumar V, Rengasamy R (2012) Mass culture of Botryococcus braunii Kutz. under open raceway pond for biofuel production. Bioresour Technol 104:394-399

5. Avila-Leon I, Chuei Matsudo M, Sato S, de Carvalho JCM (2012) Arthrospira platensis biomass with high protein content cultivated in continuous process using urea as nitrogen source. J Appl Microbiol 112:1086-1094

6. Banerjee A, Sharma R, Chisti Y, Benerjee UC (2002) Botryococcus braunii: a renewable source of hydrocarbons and other chemicals. Crit Rev Biotechnol 22:245-279

7. Bannister JV, Bannister WH, Rotilio G (1987) Aspects of the structure, function, and applications of superoxide dismutase. Ann Rev Biochem 22:110-180 
8. Basaca-Loya GA, Valdez MA, Enriquez-Guevara EA, Gutierrez-Millan LE, Burboa MG (2009) Extraction and purification of B-phycoerythrin from the red microalga Rhodosorus marinus. Cienc Mar 35:359-368

9. Beale SI (1993) Biosynthesis of phycobilins. Chem Rev 93:785-802

10. Becker EW (2007) Micro-algae as a source of protein. Biotechnol Adv 25:207-210

11. Ben-Amotz A, Avron M (1990) The biotechnology of cultivating the halotolerant alga Dunaliella. Trends Biotechnol 8:121-126

12. Ben-Amotz A, Katz A, Avron M (1982) Accumulation of $\beta$ carotene in halotolerant algae: purification and characterization of $\beta$-carotene-rich globules from $D$. bardawil (Chlorophyceae). J Phycol 18:529-537

13. Berge JP, Gouygou JP, Dubacq JP, Durand P (1995) Reassessment of lipid-composition of the diatom, skeletonema costatum. Phytochemistry 39:1017-1021

14. Bergman B (1981) Glyoxylate decreases the oxygen sensitivity of nitrogenase activity and photosynthesis in the cyanobacterium Anabaena cylindrical. Planta 152:302-306

15. Bergman B (1986) Glyoxylate induced changes in the carbon and nitrogen metabolism of the cyanobacterium Anabaena cylindrical. Plant Physiol 80:698-701

16. Bermejo R, Alvarez-Pez JM, Acien Fernandez FG, Molina Grima E (2002) Recovery of pure B-phycoerythrin from the microalga Porphyridium cruentum. J Biotechnol 93:73-85

17. Bermejo R, Talavera EM, Alvarez-Pez JM (2001) Chromatographic purification and characterization of b-phycoerythrin from Porphyridium cruentum: semipreparative HPLC separation and characterization of its subunits. J Chromatogr A 917:35-45

18. Bertheas O, Metzger P, Largeau C (1998) A high molecular weight complex lipid, aliphatic polyaldehyde tetraterpenediol polyacetal from Botryococcus braunii (L race). Phytochemistry 50:85-96

19. Bondioli P, Bella LD, Rivolta G, Zittelli GC, Bassi N, Rodolfi L, Casini D, Prussi M, Chiaramonti D, Tredici MR (2012) Oil production by the marine microalgae Nannochloropsis sp. F\&M-M24 and Tetraselmis suecica F\&M-M33. Bioresour Technol 114:567-572

20. Borowitzka MA, Huisman JM, Osborn A (1991) Culture of the astaxanthin-producing green alga Haematococcus pluvialis 1 . Effects of nutrients on growth and cell type. J Appl Phycol 3:295-304

21. Brown MR, Dunstan GA, Norwood SJ, Miller KA (1996) Effects of harvest stage and light on the biochemical composition of the diatom Thalassiosira pseudonana. J Phycol 32:64-73

22. Bujard E, Baco U, Mauron J, Mottu F, Nabholtz A, Wuhrmann JJ, Clément G (1970) Composition and nutritive value of blue green algae (Spirulina) and their possible use in food formulations. In: 3rd International Congress of Food Science and Technology, Washington, DC

23. Çelekli A, Balci M (2009) The influence of different phosphate and nitrate concentrations on growth, protein and chlorophyll a content of Scenedesmus obliquus. Fresenius Environ Bull 18:1363-1366

24. Cha KH, Koo SY, Lee DU (2008) Antiproliferative effects of carotenoids extracted from Chlorella ellipsoidea and Chlorella vulgaris on human colon cancer cells. J Agric Food Chem 56:10521-10526

25. Challouf R, Trabelsi L, Ben Dhieb R, El Abed O, Yahia A, Ghozzi K, Ben Ammer G, Omran H, Ben Ouada H (2011) Evaluation of cytotoxicity and biological activity in extracellular polysaccharides released by cyanobacterium Arthrospira platensis. Braz Arch Biol Technol 54:831-838
26. Chen CY, Yeh KL, Aisyah R, Lee DJ, Chang JS (2011) Cultivation, photobioreactor design and harvesting of microalgae for biodiesel production: a critical review. Bioresour Technol 102:71-81

27. Chisti Y (2007) Biodiesel from microalgae. Biotechnol Adv 25:294-306

28. Chiu SY, Kao CY, Tsai MT, Ong SC, Chen CH, Lin CS (2009) Lipid accumulation and $\mathrm{CO}_{2}$ utilization of Nannochloropsis oculata in response to $\mathrm{CO}_{2}$ aeration. Bioresour Technol 100:833-838

29. Choi KJ, Nakhost Z, Barzana E, Karel M (1987) Lipid content and fatty acid composition of green algae Scenedesmus obliquus grown in a constant cell density apparatus. Food Biotechnol 1:117-128

30. Choi WY, Oh SH, Seo YC, Kim GB, Kang DH, Lee SY, Jung KH, Cho JS, Ahn JH, Choi GP, Lee HY (2011) Effects of methanol on cell growth and lipid production from mixotrophic cultivation of Chlorella sp. Biotechnol Bioprocess Eng 16:946-955

31. Cohen Z (1990) The production potential of eicosapentaenoic and arachidonic acids by the red alga Porphyridium cruentum. J Am Oil Chem Soc 67:916-920

32. Cohen Z, Khozin-Goldberg I, Adlerstein D, Bigogno C (2002) The role of triacylglycerol as a reservoir of polyunsaturated fatty acids for the rapid production of chloroplastic lipids in certain microalgae. Biochem Soc Trans 28:740-743

33. Converti A, Casazza AA, Ortiz EY, Perego P, Del Borghi M (2009) Effect of temperature and nitrogen concentration on the growth and lipid content of Nannochloropsis oculata and Chlorella vulgaris for biodiesel production. Chem Eng Process 48:1146-1151

34. Dai J, Wu Y, Chen SW, Zhu S, Yin HP, Wang M, Tang J (2010) Sugar composition determination of polysaccharides from $\mathrm{Du}$ nalielle salina by modified RP-HPLC method of precolumn derivatization with 1-phenyl-3-methyl-5-pyrazolone. Carbohyd Polym 82:639-635

35. Dayananda C, Sarada R, Kumar V, Ravishankar GA (2007) Isolation and characterization of hydrocarbon producing green alga Botryococcus braunii from Indian freshwater bodies. Electron J Biotechnol 10:1-14

36. Dayananda C, Sarada R, Usha Rani M, Shamala TR, Ravishankar GA (2007) Autotrophic cultivation of Botryococcus braunii for the production of hydrocarbons and exopolysaccharides in various media. Biomass Bioenergy 31:87-93

37. Dillon JC, Phan PA (1993) Spirulina as a source of proteins in human nutrition. In: Doumengue F, Durand-Chastel H, Toulemont A (eds) Spiruline algue de vie Musée Océanographique, vol 12. Bulletin de l'Institut Océanographique Monaco, pp 103-107

38. Durmaz Y, Monteiro M, Bandarra N, Gökpinaret Ş, Işik O (2007) The effect of low temperature on fatty acid composition and tocopherols of the red microalga Porphyridium cruentum. J Appl Phycol 19:223-227

39. Fabregas J, Garcia D, Fernandez AM, Rocha AI, Gomez P, Escribano JM, Otero A, Coll JM (1999) In vitro inhibition of the replication of haemorrhagic septicaemia virus (VHSV) and African swine fever virus (ASFV) by extracts from marine microalgae. Antiviral Res 44:67-73

40. Fabregas J, Patifio M, Vecino E, Chfizaro F, Otero A (1995) Productivity and biochemical composition of cyclostat cultures of the marine microalga Tetraselmis suecica. Appl Microbiol Biotechnol 43:617-621

41. Feng Y, Li C, Zhang D (2011) Lipid production of Chlorella vulgaris cultured in artificial wastewater medium. Bioresour Technol 102:101-105 
42. Frenz J, Largeau C, Casadevall E, Kollerup F, Daugulis AJ (1989) Hydrocarbon recovery and biocompatibility of solvents for extraction from cultures of Botryococcus braunii. Biotechnol Bioeng 34:755-762

43. Guaratini T, Cardozo KHM, Pinto E, Colepicolo P (2009) Comparison of diode array and electrochemical detection in the $\mathrm{C}_{30}$ reverse phase HPLC analysis of algae carotenoids. J Braz Chem Soc 20:1609-1616

44. Garcia-Gonzales M, Moreno J, Manzano JC, Florencio FJ, Guerrero MG (2005) Production of Dunaliella salina biomass rich in 9-cis- $\beta$-carotene and lutein in closed tubular photobioreactor. J Biotechnol 115:81-90

45. Gastineau R, Pouvreau JB, Hellio C, Morançais M, Fleurence J, Gaudin P, Bourgougnon N, Mouget JL (2012) Biological activities of purified marennine, the blue pigment responsible for the greening of oysters. J Agric Food Chem 60:3599-3605

46. Gloaguen V, Ruiz G, Morvan H, Mouradi-Givernaud A, Maes E, Krausz P, Strecker G (2004) The extracellular polysaccharide of Porphyridium sp.: an NMR study of lithium-resistant oligosaccharidic fragments. Carbohydr Res 339:97-103

47. Gomez-Villa H, Voltolina D, Nieves M, Pina P (2005) Biomass production and nutrient budget in outdoor cultures of Scenedesmus obliquus (Chlorophyceae) in artificial wastewater, under the winter and summer conditions of Mazatlán, Sinaloa, Mexico. Vie et Milieu 55:121-126

48. González López CV, Cerón García MDC, Acién Fernández FG, Segovia Bustos C, Chisti Y, Fernández Sevilla JM (2010) Protein measurements of microalgal and cyanobacterial biomass. Bioresour Technol 101:7587-7591

49. Gouveia L, Nobre BP, Marcelo FM, Mrejen S, Cardoso MT, Palavra AF (2007) Functional food oil coloured by pigments extracted from microalgae with supercritical $\mathrm{CO}_{2}$. Food Chem 101:717-723

50. Gouveia L, Veloso V, Reis A, Fernandes H, Novais J, Empis J (1996) Evolution of pigment composition in Chlorella vulgaris. Bioresour Technol 57:157-163

51. Grung M, D'Souza F, Borowitzka M, Liaaen-Jensen S (1992) Algal carotenoids: 1. Secondary carotenoids 2. Haematococcus pluvialis aplanospores as a source of $\left(3 \mathrm{~S}, 3^{\prime} \mathrm{S}\right)$-astaxanthin esters. J Appl Phycol 4:165-171

52. Hagen C, Braune W, Bjorn LO (1994) Functional aspects of secondary carotenoids in Haematococcus lacustris (Volvocales). III. Action as a sunshade. J Phycol 30:241-248

53. Hagen C, Braune W, Greulich F (1993) Functional aspects of secondary carotenoids in Haematococcus lacustris [Girod] Rostafinski (Volvocales). IV. Protection from photodynamic damage. J Photochem Photobiol B Biol 20:153-160

54. Hagen C, Grünewald K (2000) Fosmidomycin as an inhibitor of the non-mevalonate terpenoid pathway depresses synthesis of secondary carotenoids in flagellates of the green alga Haematococcus pluvialis. J Appl Bot 74:137-140

55. Hayashi K, Hayashi T, Kojima I (1996) A natural sulfated polysaccharide, calcium spirulan, isolated from Spirulina platensis: in vitro and ex vivo evaluation of anti-Herpes Simplex virus and anti-human immunodeficiency virus activities. AIDS Res Hum Retroviruses 12:1463-1471

56. Ho SH, Chen CY, Chang JS (2012) Effect of light intensity and nitrogen starvation on $\mathrm{CO}_{2}$ fixation and lipid/carbohydrate production of an indigenous microalga Scenedesmus obliquus CNW-N. Bioresour Technol 113:244-252

57. Hu Q, Sommerfeld M, Jarvis E, Ghirardi M, Posewitz M, Seibert M, Darzins A (2008) Microalgal triacylglycerols as feedstocks for biofuel production: perspectives and advances. Plant $\mathbf{J}$ 54:621-639

58. Hu Z, Li Y, Sommerfeld M, Chen F, Hu Q (2008) Enhanced protection against oxidative stress in an astaxanthin- overproduction Haematococcus mutant (Chlorophyceae). Eur J Phycol 43:365-376

59. Janczyk P, Franke H, Souffrant WB (2007) Nutritional value of Chlorella vulgaris: effects of ultrasonication and electroporation on digestibility in rats. Anim Feed Sci Technol 132:163-169

60. Jaouen P, Lépine B, Rossignol N, Royer R, Quemeneur F (1999) Clarification and concentration with membrane technology of a phycocyanin solution extracted from Spirulina platensis. Biotechnol Tech 13:877-881

61. Kawachi M, Tanoi T, Demura M, Kaya K, Watanabe MM (2012) Relationship between hydrocarbons and molecular phylogeny of Botryococcus braunii. Algal Res 1:114-119

62. Khozin-Goldberg I, Cohen Z (2011) Unraveling algal lipid metabolism: recent advances in gene identification. Biochimie 93:91-100

63. Knothe G (2006) Analyzing biodiesel: standards and other methods. J Am Oil Chem Soc 83:823-833

64. Kobyashi M, Kakizono T, Nagai S (1991) Astaxanthin production by a green alga, Haematococcus pluvialis accompanied with morphological changes in acetate media. J Ferm Bioeng 71:335-339

65. Lankester R (1986) On green oysters. Q J Microsc Sci 26:71-94

66. Laroche C, Michaud P (2007) New developments and prospective applications for $\beta(1,3)$ glucans. Rec Pat Biotechnol 1:59-73

67. Laws EA, Pei S, Bienfang P, Grant S (2011) Phosphate-limited growth and uptake kinetics of the marine prasinophyte Tetraselmis suecica (Kylin) Butcher. Aquaculture 322-323:117-121

68. Lee JY, Yoo C, Jun SY, Ahn CY, Oh HM (2010) Comparison of several methods for effective lipid extraction from microalgae. Bioresour Technol 101:S75-S77

69. Lehninger AL, Nelson DL, Cox MM (2005) Lehninger principles of biochemistry, 4th edn. W.H. Freeman, New York

70. Lee RE (2008) Phycology, 4th edn. Cambridge University Press, Cambridge

71. Levy-Ontman O, Arad SM, Harvey DJ, Parsons TB, Fairbanks A, Tekoah Y (2011) Unique $N$-glycan moieties of the 66-kDa cell wall glycoprotein from the red microalga Porphyridium sp. J Biol Chem 286:24340-21352

72. Liska AJ, Shevchenko A, Pick U, Katz A (2004) Enhanced photosynthesis and redox energy production contribute to salinity tolerance in Dunaliella as revealed by homology-based proteomics. Plant Physiol 136:2806-2817

73. Liu Y, Wang W, Zhang M, Xing P, Yang Z (2010) PSII-efficiency, polysaccharide production, and phenotypic plasticity of Scenedesmus obliquus in response to changes in metabolic carbon flux. Biochem Syst Ecol 38:292-299

74. Lorenz RT, Cysewski GR (2000) Commercial potential for Haematococcus microalgae as a natural source of astaxanthin. Trends Biotechnol 18:160-167

75. Mahboob S, Rauf A, Ashraf M, Sultana T, Sultana S, Jabeen F, Rajoka MI, Alkaham Al-Balawi HF, Al-Ghanim KA (2012) High-density growth and crude protein productivity of a thermotolerant Chlorella vulgaris: production kinetics and thermodynamics. Aquacult Int 20:455-466

76. Mandal S, Mallick N (2009) Microalga Scenedesmus obliquus as a potential source for biodiesel production. Appl Microbiol Biotechnol 84:281-291

77. Mandal S, Mallick N (2011) Waste utilization and biodiesel production by the green microalga Scenedesmus obliquus. Appl Environ Microbiol 77:374-377

78. Mata TM, Martins AA, Caetano NS (2010) Microalgae for biodiesel production and other applications: a review. Renew Sust Energ Rev 14:217-232

79. Mendes RL, Fernandes HL, Coelbo JP, Reis EC, Cabral JMS, Novais JM, Palavra AF (1995) Supercritical $\mathrm{CO}_{2}$ extraction of 
carotenoids and other lipids from Chlorella vulgaris. Food Chem 53:99-103

80. Mendes RL, Nobre BP, Cardoso MT, Pereira AP, Palavra AF (2003) Supercritical carbon dioxide extraction of compounds with pharmaceutical importance from microalgae. Inorg Chim Acta 356:328-334

81. Mendes-Pinto MM, Raposo MFJ, Bowen J, Young AJ, Morais R (2001) Evaluation of different cell disruption processes on encysted cells of Haematococcus pluvialis: effects on astaxanthin recovery and implications for bio-availability. J Appl Phycol 13:19-24

82. Metzger P, Allard B, Casadevall E, Berkaloff C, Coute A (1990) Structure and chemistry of a new chemical race of Botryococcus braunii (Chlorophyceae) that produces lycopadiene, a tetraterpenoid hydrocarbon. J Phycol 26:258-266

83. Mishra A, Kavita K, Jha B (2011) Characterization of extracellular polymeric substances produced by micro-algae Dunaliella salina. Carbohydr Polym 83:852-857

84. Neuville D, Daste PH (1978) Recherche sur le déterminisme de la production de marennine par la diatomée marine Navicula ostrearia (Gaillon) Bory en culture in vitro. Revue Générale de Botanique 85:255-303

85. Nomoto K, Yokokura T, Satoh H, Mutai M (1983) Anti-tumor effect by oral administration of Chlorella extract, PCM-4 by oral admission. Gan To Kagaku Zasshi 10:781-785

86. Ogawa K, Ikeda Y, Kondo S (1999) A new trisaccharide, alphaD-glucopyranuronosyl-(1 $\rightarrow$ 3)-alpha-L-rhamnopyranosyl-

$(1 \rightarrow 2)$-alpha-L-rhamnopyranose from Chlorella vulgaris. Carbohydr Res 321:128-131

87. Oliver DJ, Zelitch I (1977) Metabolic regulation of glycolate synthesis, photorespiration, and net photosynthesis in tobacco by L-glutamate. Plant Physiol 59:688-694

88. Olofsson M, Lamela T, Nilsson E, Bergé JP, del Pino V, Uronen P, Legrand C (2012) Seasonal variation of lipids and fatty acids of the microalgae Nannochloropsis oculata grown in outdoor large-scale photobioreactors. Energies 5:1577-1592

89. Patel AK, Laroche C, Marcati A, Ursu AV, Jubeau S, Marchal L, Petit E, Djelveh G, Michaud P (2013) Separation and fractionation of exopolysaccharides from Porphyridium cruentum. Bioresource Technol (in press)

90. Patel A, Mishr S, Pawar R, Ghosh PK (2005) Purification and characterization of C-phycocyanin from cyanobacterial species of marine and freshwater habitat. Protein Expres Purif 40:248-255

91. Philippis R, Sili C, Vincenzini M (1996) Response of an exopolysaccharide-producing heterocystous cyanobacterium to changes in metabolic carbon flux. J Appl Phycol 8:275-281

92. Pouvreau JB, Morançais M, Massé G, Rosa P, Robert JM, Fleurence J, Pondaven P (2006) Purification of the blue-green pigment "marennine" from the marine tychopelagic diatom Haslea ostrearia (Gaillon/Bory) Simonsen. J Appl Phycol 18:769-781

93. Pouvreau JB, Morançais M, Taran F, Rosa P, Dufossé L, Guérard F, Pin S, Fleurence J, Pondaven P (2008) Antioxidant and free radical scavenging properties of marennine, a blue-green polyphenolic pigment from the diatom Haslea ostrearia (Gaillon/Bory) Simonsen responsible for the natural greening of cultured oysters. J Agric Food Chem 56:6278-6286

94. Ramus J (1981) The capture and transduction of light energy. In: Lobban CS, Wynne MJ (eds) The biology of seaweeds. Blackwell Scientific Publications, Boston, pp 458-492

95. Ranga Rao A, Dayananda C, Sarada R, Shamala TR, Ravishankar GA (2007) Effect of salinity on growth of green alga Botryococcus braunii and its constituents. Bioresour Technol 98:560-564
96. Ranson G (1927) L'absorption de matières organiques dissoutes par la surface extérieure du corps chez les animaux aquatiques. Annales de l'Institut Océanographique 4:49-174

97. Raposo MPJ, Morais RMSC, Morais AMMB (2013) Bioactivity and applications of sulphated polysaccharides from marine microalgae. Mar Drugs 11:233-252

98. Rebolloso Fuentes MM, Acien Fernandez GG, Sanchez Perez JA, Guil Guerrero JL (2000) Biomass nutrient profiles of the microalga Porphyridium cruentum. Food Chem 70:345-353

99. Rossignol N, Jaouen P, Robert JM, Quéméneur F (2000) Production of exocellular pigment by the marine diatom Haslea ostrearia Simonsen in a photobioreactor equipped with immersed ultrafiltration membranes. Bioresour Technol 73:197-200

100. Ruen-Ngam D, Shotipruk A, Pavasant P, Machmudah S, Goto M (2012) Selective extraction of lutein from alcohol treated Chlorella vulgaris by supercritical $\mathrm{CO}_{2}$. Chem Eng Technol 35:255-260

101. Ruiz-Martin A, Mendoza-Espinosa G, Stephenson T (2010) Growth and nutrient removal in free and immobilized green algae in batch and semi-continuous cultures treating real wastewater. Bioresour Technol 101:58-64

102. Sakamoto K, Baba M, Suzuki I, Watanabe MM, Shiraiwa Y (2012) Optimization of light for growth, photosynthesis, and hydrocarbon production by the colonial microalga Botryococcus braunii BOT-22. Bioresour Technol 110:474-479

103. Sarada R, Pillai MG, Ravishankar GA (1999) Phycocyanin from Spirulina sp: influence of processing of biomass on phycocyanin yield, analysis of efficacy of extraction methods and stability studies on Phycocyanin. Process Biochem 34:795-801

104. Schwenzfeier A, Wierenga PA, Gruppen H (2011) Isolation and characterization of soluble protein from the green microalgae Tetraselmis sp. Bioresour Technol 102:9121-9127

105. Seyfabadi J, Ramezanpouret Z, Khoeyi ZA (2011) Protein, fatty acid, and pigment content of Chlorella vulgaris under different light regimes. J Appl Phycol 23:721-726

106. Singh S, Arad SM, Richmond A (2000) Extracellular polysaccharide production in outdoor mass cultures of Porphyridium sp. in flat plate glass reactors. J Appl Phycol 12:269-275

107. Sommer TR, Pott WT, Morrisey NM (1991) Utilization of microalgae astaxanthin by rainbow trout (Oncorhynchus mykiss). Aquaculture 94:79-88

108. Stephenson PG, Moore CM, Terry MJ, Zubkov MV, Bibby TS (2011) Improving photosynthesis for algal biofuels: toward a green revolution. Trends Biotechnol 29:615-623

109. Su CH, Chien LJ, Gomes J, Lin YS, Yu YK, Liou JS, Syu RJ (2011) Factors affecting lipid accumulation by Nannochloropsis oculata in a two-stage cultivation process. J Appl Phycol 23:903-908

110. Sukenik A, Carmeli Y, Berner T (1989) Regulation of fatty acid composition by irradiance level in the eustigmatophyte Nannochloropsis sp. J Phycol 25:686-692

111. Sun L, Wang C, Shi QJ, Ma CH (2009) Preparation of different molecular weight polysaccharides from Porphyridium cruentum and their antioxidant activities. Int J Biol Macromol 45:42-47

112. Sun L, Wang L, Zhou Y (2012) Immunomodulation and antitumor activities of different-molecular-weight polysaccharides from Porphyridium cruentum. Carbohydr Polym 87:1206-1210

113. Thornton DCO (2002) Diatom aggregation in the sea: mechanisms and ecological implications. Eur J Phycol 37:149-161

114. Tonon T, Harvey D, Larson TR, Graham IA (2002) Long-chain polyunsaturated fatty acid production and partitioning to triacylglycerols in four microalgae. Phytochemistry 61:15-24

115. Trabelsi L, Ben Houada H, Zili F, Mazhoud N, Ammar J (2013) Evaluation of Arthrospira platensis extracellular polymeric 
substance production in photoautotrophic, heterotrophic and mixotrophic conditions. Folia Microbiol 58:39-45

116. Trabelsi L, M'sakni NH, Ben Houada H, Bacha H, Roudesli S (2009) Partial characterization of extracellular polysaccharide produced by Arthrospira platensis. Biotechnol Bioprocess Eng 14:27-31

117. Uslu L, Isik O, Koç K, Göksan T (2011) The effects of nitrogen deficiencies on the lipid and protein contents of Spirulina platensis. Afr J Biotechnol 10:386-389

118. Velea S, Ilie L, Filipescu L (2011) Optimization of Porphyridium purpureum culture growth using two variables experimental design: light and sodium bicarbonate. U.P.B. Sci Bull Ser B 73:86-94

119. Vigeolas H, Duby F, Kaymak E, Niessen G, Motte P, Franck F, Remacle C (2012) Isolation and partial characterization of mutants with elevated lipid content in Chlorella sorokiniana and Scenedesmus obliquus. J Biotechnol 162:3-12

120. Vílchez C, Garbayo I, Lobato MV, Vega JM (2007) Microalgaemediated chemicals production and wastes removal. Enzyme Microb Technol 20:562-572
121. Wang B, Zarka A, Trebst A, Boussiba S (2003) Astaxanthin accumulation in Haematococcus pluvialis (Chlorophyceae) as an active photoprotective process under high irradiance. J Phycol 39:1116-1124

122. Wilson MA, Batts BD, Hatcher PG (1988) Molecular composition and mobility of torbanite precursors: implications for the structure of coal. Energy Fuels 2:668-672

123. Ye ZW, Jiang JG, Wu GH (2008) Biosynthesis and regulation of carotenoids in Dunaliella: progresses and prospects. Biotechnol Adv 26:352-360

124. Yeh KL, Chang JS (2012) Effects of cultivation conditions and media composition on cell growth and lipid productivity of indigenous microalga Chlorella vulgaris ESP-31. Biochem Eng J 64:1-7

125. Zhekisheva M, Boussiba S, Khozin-Goldberg I, Zarka A, Cohen $\mathrm{Z}$ (2002) Accumulation of oleic acid in Haematococcus pluvialis (Chlorophyceae) under nitrogen starvation or high light is correlated with that of astaxanthin esters. J Phycol 38:325-331 